\title{
Critique of Racism in the "Waktu Indonesia Timur" Program on NET TV
}

\author{
Rosalia Prismarini Nurdiarti ${ }^{1 *}$, Rani Dwi Lestari ${ }^{1}$ \\ ${ }^{1}$ Faculty of Communication \& Multimedia, Universitas Mercu Buana Yogyakarta, Yogyakarta, Indonesia \\ "Corresponding author. Email: rosa@mercubuana-yogya.ac.id
}

\begin{abstract}
Intolerance, conflict, cultural disorientation and racial discrimination are trends in socio-cultural pathology which are relatively easy to find today. These events are recorded in Indonesian territory and are an actual reference to raise the problem. Indonesia, which consists of various races, ethnicities, religions and groups, has the potential to create tension and discriminatory treatment. The rise of ethnicity culminates in demands for recognition of cultural identity and self-esteem. What happens on a daily basis also surfaces in the television media, the issue of SARA being a commodity that is becoming public consumption. One of the highlights when there was criticism about racism through humour. This study aims to understand how criticism of racism is constructed in humour stand-up comedy. The method used is the analysis of Norman Fairclough critical discourse, with a three stages of discourse practice at the micro level (audio-visual text), meso level (consumption and production of text) and macro level (connecting the networks of text to social condition). The results of this study, the existence of stereotypes about the backward and temperamental East Indonesian people, the existence of language, culture and accent typical of Eastern Indonesia, racism criticism comes through satirical humour to prosperity and infrastructure that is still minimal.
\end{abstract}

Keywords: racism, humour, Eastern Indonesia

\section{INTRODUCTION}

The issue of Ethnic Religion and Race (SARA) in recent years has been sharper. Some cases of intolerance and conflict that lead to anarchism make the community more acute in the utterance of hate or slander. In Indonesia, one of the sharpest discriminations is the conditions and people in Eastern Indonesia who are still left behind. But now the government has begun to pay attention to the infrastructure in this area, only a few things that have not been able to be minimized are the stereotypes of Eastern Indonesians who are considered to be lagging behind aspects of their knowledge, attitudes and way of thinking about life. This was conveyed through a joke in the "Waktu Indonesia Timur" (WIT). This program presents several comedians who in each segment are more likely to laugh at themselves (as easterners) for the discrimination they receive. Through the jokes that were delivered, the research wanted to understand the forms of criticism of racism and discrimination that were received by the eastern community in the WIT.

Humour is obtained by observing social phenomena, analyzing, compiling, then conveying it through humour. Even though Stand Up Comedy is a part of the comedy world, but there is something unique about its nature or in the perspective of communication, the communication style of comics in Stand Up Comedy is not just talking like a comedian and conventional jokes style but here it refers more to criticism and satire which is packaged in a comedian style so that in addition to entertaining they also channel people's aspirations towards the phenomena that are happening now and that also becomes new knowledge for the public.

During the stand-up comedy competition booming on national television, some of the winners began to be drawn to fill comedy programs with quiz or talk shows and similar entertainment programs. From a variety of entertainment programs that have been present, the narration in attendance takes a lot of Jakarta-style humour. The presence of the program "Waktu Indonesia Timur" brings its own color to the world of entertainment in Indonesia, remembering jokes and issues raised around the daily lives of people in Eastern Indonesia, even the people involved in the event also entered to give the concept in the event .

In some studies the issue of racism is rarely raised because it is one of the sensitive things in Indonesia. Several studies that are approached are related to the construction of cultural identity. Research from Khotimah on [1]: "Construction of Cultural Identity "Wong Ngapak" through the consumption of local media in the Banyumasan dialect ", the example of the case raised here is the Javanese radio broadcast of the Bayumas dialect "Curanmor" by students from Cilacap in Yogyakarta. With ethnographic methods, trying to examine identity and positioning of cultural identity in a central perspective and periphery. From the results of the analysis it was obtained, that through the consumption of local media by students from Cilacap the construction of cultural identity was drawn, including "Curanmor as a cultural marker of the blessing of the Banyumas community. This broadcast is also a way back" to my hometown. On the other hand, it is also a cultural differentiator, as a soft resistance to marginalization of Banyumasan culture. 
Subsequent research from Suryandari on [2] : the existence of cultural identity in a multicultural society and the insistence of global culture. One effort to preserve cultural identity without causing conflict in multicultural societies while at the same time becoming a fortress in the midst of global cultural attacks is the existence of mindful communication between cultures so as to create harmony and social cohesiveness. Communication between mindful cultures will emerge when each party that establishes contact or interaction can minimize cultural misunderstandings, namely efforts to reduce ethnocentric behaviour, prejudice and stereotypes. In addition, mindfulness in communication between cultures will also be achieved if both parties can manage it well.

Specifically the discussion of racism is motivated by cultural identity. As stated by Rummens that cultural identity can be interpreted in various ways including for example as a distinctive marker or differentiator, though often impressed imaginative, which exists or is attached to a society (including the state / national society) [3]. With cultural identity in question can be distinguished between the community concerned with other communities. Based on Rummens' observations, it can be understood how cultural identity is usually felt to be very important by members of the community / nation in contact everywhere, especially because cultural identity can function, other than as a marker or differentiator, it also functions as a bond of togetherness (which unites all members of the community), as wealth and nationality (cultural heritage that provides a kind of spirit, which must therefore always be an external force when interacting with other communities.

One theory related to the issue of negotiation or identity management in order to realize communication between mindful cultures is the result of thoughts from Collier \& Thomas, namely cultural identity theory [4]. Thomas presents an interpretive theory of how cultural identity is managed in cultural interaction. This theory is stated in assumptions, 5 axioms and 1 theorem. The assumptions underlying the theory of cultural identity are 1 . individuals negotiate identity in a discourse. 2. Intercultural communication takes place through discursive assumptions and recognition of different cultural identities. 3 . Intercultural communication competencies include coherent management of meaning and interest in following rules and positive outcomes. 4. Intercultural communication competencies include the negotiation of shared meanings, rules and positive outcomes.

In looking at cultural identity, reviewers of communication and media use at least three approaches [5]. First, textual analysis, audience analysis and political economy to explain cultural phenomena. Textual analysis, is the reading and interpretation of cultural meanings, including the study of books, films or television programs. Structuralist media theory will point to how films and television programs "position viewers" and "construct subjectivities" according to certain ideological positions. In this case, it can use discourse and ideological analysis that forms the discourse of media and cultural texts [6].

In this case identity management will be one of the things that will be observed in the show "Eastern Indonesia Time" with a sense of humour. Everyone has their own way of expressing their desires or feelings. Humour is one way to convey something indirectly. As one of the linguistic phenomena, humour can be found in various places in various forms. This includes representing problems or issues that often arise in the daily lives of Eastern Indonesian people.

\section{RESEARCH METHODS}

In this research the method used is critical discourse analysis. This discourse analysis manifests in the use of texts and visuals produced in WIT. Critical Discourse Analysis is of the view that discourse or use of language can be a place where power lies, ie unequal or unequal relations between two parties. It should be emphasized that discourse needs to be understood as a form of language use, both verbally and in writing. The use of language can represent power. The use of language can be ideological, that is, language can represent ideology. Ideology is a certain way of representing and shaping society by reproducing an unbalanced power relation, that is the relationship of domination and exploitation [7].

Power is an unequal or unequal relationship between one party and another party. In power there is a relationship of domination, that is, there are those who dominate the socalled authorities and there are those who are dominated, subordinated, or marginalized [8]. Based on its scope, domination can include the domination of one nation over another nation, the dominance of one state over another country, the dominance of the state over its people, the dominance of certain groups over other groups, or the dominance of individuals over other individuals. Based on the source, dominance can be found in the economic, political, racial, gender, social, and cultural fields.

Specifically, the discourse analysis used in this study is the Fairlough discourse analysis which emphasizes the constellation of forces that occur in the process of production and reproduction of meaning. In the context of discourse, there are specific practices of discernment in which texts are produced and consumed or interpreted. Every language use event is a communicative event consisting of three dimensions, namely text (speech, visual imaging or a combination of the three), the practice of discourse that involves the production and consumption of texts and social practices.

These three dimensions are explained as follows, text analysis is centered on formal features (vocabulary, grammar, syntax and sentence coherence) and that's where linguistic discourse and flow are realized. The relationship between text and social practice is mediated by the practice of citizenship. The flow of discourse is realized together to produce a text and the recipient is manifested to carry out the interpretation. These dimensions will be seen through the text or language used in the WIT program, then see the visual aspects that are often displayed in WIT and then the intertextual relationship will be seen from the discourse field socially, politically and culturally surrounding the WIT program

Discourse practice is a dimension related to the process of producing and consuming text. A text is basically produced through work patterns, work charts and routines in producing texts (for example news or program programs) 
the process of consuming texts is also different in different social contexts. In the WIT program, this can be seen from the interpretation of the audience and creative team in producing ideas or content. So the background of the creative team, the majority from Eastern Indonesia, will influence their narratives in presenting problems about Eastern Indonesia. Sociocultural practice is a dimension related to context outside the text. The context here includes many things, such as the context of the situation, more broadly is the context of the practice of the media institutions themselves in their particular community or cultural and political relations. In this context, the WIT program is seen as a media product entity that is inseparable from the interests of audience ratings, tastes and media policy.

\section{RESULTS AND DISCUSSION}

\subsection{Discourse in the Program "Waktu Indonesia Timur"}

Daramjwi's story begins with a narrative explaining that Daramjwi character was born in Korea and had a life in the Korean War situation. The Korean War happened in 19501953. As a result of this war, more than 4,000 orphans spread out throughout the Korean Peninsula [19]. This war not only caused physical death, but it also indirectly killed the psychological and spiritual aspects of the children. They lost their parents and had to live alone. Many children were starving because they were not able to find their own food, especially in war situations. The situation became worse during the winter. More and more orphans died and frozen. For the sake of getting something to eat, children who were the victims of this war often followed the American army. They usually received a bar of chocolate or nuts from American soldiers.

"Dari Sabang Sampai Merauke, Dari Miangas Sampai Pulau Rote, Kami Hadir untuk Menghibur, Karena Kami di Waktu Indonesia Timur"......("From Sabang to Merauke, from Miangas to Rote Island, we are here to entertain, because we were in Eastern Indonesia") It was a fragment of the opening comedy program "Waktu Indonesia Timur" (WIT) on NET TV. The program premiered on April 7, 2018 and was guided by Ari Kriting and Abdur in raising the territory of Eastern Indonesia. In addition to relying on accent, the host and cast WIT have qualified comedy skills. They are dropouts of comic search and are active as comedians on film or stage. Call it Arie Kriting, Abdur Arsyad, Jhon Yewen, Obi Messakh, and Reinold Lawalata. Similarly, when watching WIT. Not only became familiar with the typical dialogue, the audience was invited to laugh many times for about an hour. In addition to jokes cast by sitcoms or scenes from sitcoms, the accent typical of Eastern Indonesia sometimes invites laughter. Although some sound like anger, not a few are funny.

During this time, their talents that often appear are singing and music. WIT became one of the ways to introduce other talents from Eastern Indonesians, namely to be funny. With the appointment of these talents, Eastern Indonesia is not merely a matter of exotic beaches, savannas, indigenous cultures, or even backwardness. This is because the media in Indonesia have discussed this matter too often, leaving aside the other talents of the people there. The presence of WIT is expected to break the stereotype that the East Indonesian people are identical with temperamental traits. It is not difficult for the hosts and cast to joke. When a family event or gathering with friends, they throw each other funny stories or jokes. The comics at WIT are often asked to make jokes when they are with their family or friends.

The program consists of several segments, namely impromptu sitcom segments such as Two Enough, Short Scenes, Whose Sentences, Mutual Sketches, and Expert Experts. In these segments, the comics are only given improvised material and direction. For example, two sentences or a description of the situation. The rest, they are free to create spontaneously. The lack of directives is actually beneficial. The comics have room to improvise to bring fresh humour. Natural and simple. Not infrequently, they do funny action. For example, Yewen who has the courage to say "cute" in a cute style. Or, when Abdur who is a Larantuka person should say the typical Ngapak style in Central Java. The comics are also good at adjusting to the guest stars present. For example, through the Sweet Seating segment which is packaged as a talk show. Through this segment too, illustrated their typical hospitality.

In order to strengthen the impression that Eastern Indonesia is full of talent, the occasional invited guest has the blood of the region. For example, Joanita Veroni, Marion Jola, Nowela Auparay, even Prilly Latuconsina. In addition, songs that were played during the program were performed by Hitam Manis, a home band with members of East Indonesian blood. Another strength that distinguishes comedy shows in general is because WIT adopts the concept of culture from the East, so it has clear differentiation so that it's easy to remember. The cuteness that comes through this event is also natural, getting something funny through a simple or gimmick method that is easy and doesn't require too much preparation. The element of regionalism which is very strong from WIT will allow it to have many fans, even fanatics. From the name of the event that carries the element of "east", this will have a personal closeness with a handful of certain circles.

The program "Waktu Indoensia Timur" (WIT) is motivated by the presence of another program on NET TV namely "Waktu Indonesia Bercanda" (WIB) [9]. Then the producers at NET TV tried to make another program, WIT. In addition, NET TV has a high standard in determining the program. The programs that aired are expected to be remembered to have their own identity. When brainstorming the prouser invited one of the comics from Eastern Indonesia to determine the concept of the event. Specifically, the purpose of this event was to provide an opportunity for East Indonesian comedians in Indonesian television. Another strength to be highlighted from this event is the content and jokes presented departing from the unrest of the people of Eastern Indonesia.

During the selection process the comedians were drawn from the contestants in the stand up comedy competition at Indosiar and also the senior comics. With regard to segmentation in the program, determined by the comics. 
Some basic games and improvisations that are done are already used to being done at community stand ups. They also went through a research process, so that the jokes delivered had a strong background and a true story so that there were no hoax issues in the future. When viewed from several segments displayed, they are very focused on spontaneity and improvisation. However, it is still intended to convey an issue related to daily life, social, cultural, political, and economic.

Societal racism is constituted in the cultural ambience produced by the entrenched social orders and includes the values, epistemologies, norms and sensibilities that attach to hegemonic power. Institutional racism is produced in this context through the organisational requirements, conditions, practices, policies and processes that maintain and reproduce avoidable and unfair inequalities across ethnic/racial groups. At the interpersonal level the myriad direct interactions between people across power differentials enact inequities that are cumulative with the higher level infl uences, reinforcing and materialising their impact [10]

From the concept above, social racism in the WIT program comes through ridicule about low intellect. In addition, physical stereotypes that appear several times, for example "black", "curly", "loud noise". Institutional racism arises through government policies that pay more attention to development in Java than in Eastern Indonesia, this arises through the narratives presented by comedians in their jokes. Racism at an interpersonal level, on the WIT program comes out through sentences that imply that dating Eastern Indonesians is always disappointing and easily broken. In relationships also are more often in tension because of their hard nature. These discourses are reproduced at each episode in the WIT program.

\subsection{Construction of Racism in the Media}

Human perception of everything that goes on around him is built from an awareness of the existence of values that guide humans to define cultural reality. Individuals in their lives interact with other human beings, ally, forming families and ultimately forming societies. From there then individuals try to understand something, attach meaning to certain events and try to live a daily reality based on values believed. In the larger system, individuals never escape from the socialization of values that take place in the social space. Many values were adopted, although it did not rule out negotiation space. From that process, finally there is a value attached to the individual and the value received.

From the media sector, the strengthening of the role and dominance of the mass media in various fields of community life has led to the media also playing an important role as a means of socializing values, outside the values of the media itself. When a discourse or value is transferred through the media, many possibilities occur. The concern is when there is a reduction in the discourse or values. However the process of producing messages in the media must follow a certain standard or procedure framework. A number of media theorists offer explanations that assume that the transfer of messages from one room to another is not merely transferring messages [11]. But it is a change in the mode of production that has implications for the level of individuals, institutional and sociocultural. Several approaches are needed to understand the importance of sociocultural media in daily life. The media as constructors and shapers, see that the content distributed by the media has the power to influence the future of society. Media as a mirror, is to reflect back on us important events, behaviors, identities or values. This perspective has given birth to research that examines changes in structure, cultural or political norms in real society by examining media content.

From this approach, a view emerged to understand both of them as circular relations. This means that the media presents a composition of world representations that have been selected and packaged in such a way. The circular media representation model is useful for understanding the importance of the media in a sociocultural manner [12]. This model can understand the ongoing process of selective media representation and how it is influenced by the packaging and character of our society. Described through the following model. Repeated pressures on certain opinions, themes, events or practices through the media and constant exclusion of others can have consequences for future social patterns, attitudes, identities and behavior.

Seeing how the media operate and influence modern human life, can be viewed from cultural theory and the media. Culture is not only defined through text, but also relates to patterns of life and thought and all human activities. Teori media - culture is related not only to mass media content, but also to the context of production and acceptance as well as all the practices that surround it. James Carey sees culture as a process, but can also refer to the shared attributes of a group of people (for example, works of art and architecture) which symbolize certain meanings and for people with certain cultural characteristics [13].

All aspects of production and use of mass media have a cultural dimension. Dimensions can focus on people as producers of media texts that are culturally meaningful, or as readers of texts that take on cultural significance with an impact on our entire social life. Cultural perspectives are more interested in seeing how media influences the daily lives of individuals. This theory is at the micro or microscopic level, because it prioritizes questions that involve the daily lives of ordinary people in their experiences with the media. But instead cultural theory at the macri (macroscopic) level looks at how overall social broadcasts are influenced.

The media can then be seen as a cultural industry, according to Nicholas Garnham in Emancipation The Media and Modernity, the media are seen as a system of production, distribution and consumption of symbolic forms which increasingly require the mobilization of scarce resources both material and cultural [14]. At the macro level, he argues that elites sometimes use the media to propagate hegemonic culture as a means to maintain their dominant position in the social fabric. They also tried hard to make use of the media to create and market cultural commodities, which were apolitical in nature to ensure profitability for these elites. This further confirms that the media is an industry that specializes in the production and distribution of culture. 
Mass media is one of the spaces in which humans interact with one another, so the media are often considered to have the power to build meaning for the community. The media is considered to have a role in building a paradigm that grows in society, including in this case culture. Through the media, culture is mass produced and disseminated in direct competition with locally based cultures. The development of the media industry has had a small impact on local producers. So that the elite are able to impose and disrupt the culture of daily life. Local culture began to disappear eroded by the culture of entertainment culture on television. They mix and package it to create an attractive cultural content, then market the results as a substitute for everyday people's cultural forms. The culture industry (media) is a process that gives birth to new forms of cultural commodification.

The description of Transnational Communication and Cultural Industries is one of the earliest descriptions and quite important theoretical talks about how the early development of the cultural industry across national borders, as an important part of the ongoing process of trans nationalisation of the culture and communication industry. Another characteristic is trans nationalization (sometimes called internationalization) of mass media and global scale organizations, called transnational cultural industries. The cultural implications of this transnational are multidimensional in nature. They see communication as an important part of economic and cultural life, especially it must be protected from foreign penetration, because it is considered important for national and cultural identity, and improvement in quality of life.

Furthermore, there are two different approaches in examining the trans nationalization of the culture industry, specifically to curb the flow of international television programs. First, a purely business perspective, shows the role of the dominates of American television program exports since the early 1980 s which increased compared to the 1970s. Second, a cultural approach to studying the distribution of television programs throughout the world will emphasize that the quantity of program time that is imported and watched in developing countries, whether free or low cost, is equally important because of the social, cultural and political impacts that program material will cause. imported ones. The increase in imports of television programs is a logical implication of the trans nationalization of the cultural industry.

Some observers call it colonization and cultural and media imperialism. But even that view also received criticism from a perspective that saw that globalization also creates adaptation and cultural accommodation through the process of "globalization". In Tomlison's view, an important vision is the transformation from locality to globality. This phenomenon as a hybrid culture or like the logic of globalization culture which is called "hybridization". Problems will arise when reconciliation of one's own culture with a new culture is not possible. The path taken usually takes one of the cultural or psychological conflicts that arise, especially if the new culture or values are considered to be totally at odds with the values that have been held so far.

\section{CONCLUSION}

Racism criticism that was developed through the Eastern Indonesia Time Program can be identified in several aspects. In each of their performances and jokes, Abdur and Arie Kriting as well as several talents from Eastern Indonesia, conveyed the meaning of the conditions that existed in Eastern Indonesian society. Some of these portrayals are in terms of disadvantaged areas, minimal access to technology. The region has lagged behind in terms of infrastructure development. On the other hand, it also shows the government's discrimination over regional development there. Social conditions that are still experiencing inequality and inequality. The unrest over social phenomena was conveyed through comedy in the form of satire. Policy issues also often become the topic of their jokes. Another thing that emerged was related to racial discrimination and stigma experienced by the people of Eastern Indonesia. The WIT comedy stage in the end did not just stop at the joke, but as a means to convey anxiety and how the conditions of people in East Nusa Tenggara are still far from decent and prosperous.

Literature on diaspora that has ideas and concepts about Korea needs to be included in the history of Korean literature. This research is still very narrow because it only sees the condition of the Goryeoin identity crisis from just one novel. Further research is needed to gain more understanding of the identity crisis, especially the cultural crisis, which experienced by Goryeoin.

\section{ACKNOWLEDGMENT}

We thank you very much for the financial support from the Mercu Buana University Yogyakarta Research and Service Institute. Secondly, in the research resource, the creative program "Waktu Indonesia Timur", Bung Akbar and the performers of Bung Yewen. Third, the two students who helped to collect data and literature in this study. Fourth, the Faculty of Communication and Multimedia for their support in the discussion for this research

\section{AUTHOR CONTRIBUTIONS}

Conceptualization (R.P.N, R.D.L); Material research preparation (R.D.L); Methodology (R.P.N); Data collecting (R.P.N, R.D.L); Data analysis and visualization (R.P.N, R.D.L); Writing - original draft (R.P.N, R.D.L); Presentation (R.P.N).

\section{REFERENCES}

[1] Khotimah, "Konstruksi Identitas Kultural "Wong Ngapak" Melalui Konsumsi Media Dialek

Banyumasan," Studi Budaya Nusantara, vol. I, no. 02, pp. 11-19, 2017. 
[2] Suryandari, "Eksistensi Identitas Kultural Di Tengah Masyarakat Multikultur," Komunikasi , vol. XI, no. 1, pp. 21-28, 2017.

[3] D. Holmes, Komunikasi, Media, Teknologi dan Masyarakat, Yogyakarta: Pustaka Pelajar, 2012.

[4] J. B. Thompson, Kritik Ideologi Global, Yogyakarta: IRCiSOD, 2015.

[5] B. A. Idi Ibrahim, Komunikasi dan Komodifikasi, Jakarta: Obor, 2014.

[6] L. Christiani, "Representasi Identitas Etnis Papua Dalam Drama Remaja Diam-Diam Suka," Jurnal Komunikasi dan Kajian Media, vol. I, no. 01, pp. 15-30, 2017.

[7] R. Wodak, Methods of Critical Discourse Analysis, London: Sage Publication, 2001.

[8] N. Fairclough, Language and Power, USA:

Longman Inc, 1998.

[9] B. Akbar, Interviewee, Background of WIT. [Interview]. 23 September 2019.

[10] T. K. B. B. M. T. Barnes Angela, "Maori Experiences and Responses To Racism in Aotearoa New Zealand," Mai Journal, vol. 2, no. 2, pp. 63-77, 2014.

[11] S. Astuti, "Program Sahur Ramdhan di TV : Analisis Wacana Kritis," in Metode Penelitian

Komunikasi, Bandung, Remaja Rosda Karya, 2013, pp. 201-220.

[12] I. Ibrahim, Budaya Populer Sebagai Komunikasi, Yogyakarta: Jalasutra, 2011.

[13] McQuail, Teori Komunikasi Massa, Jakarta: Salemba Humanika, 2011.

[14] L. P. Marianne Jorgensen, Analisis Wacana : Teori dan Metode, Yogyakarta: Pustaka Pelajar, 2010. 